University of Nebraska - Lincoln

DigitalCommons@University of Nebraska - Lincoln

\title{
EFFECT OF PLANTING DATE, NITROGEN RATE, AND HYBRID ON SUNFLOWER
}

\author{
Valtcho D. Zheljazkov \\ Mississippi State University, vjeliazk@uwyo.edu \\ Brady A. Vick \\ Sunflower Research Unit, USDA-ARS, Northern Crop Science Laboratory, Fargo, North Dakota \\ Brian S. Baldwin \\ Mississippi State University, bsb2@msstate.edu \\ Normie Buehring \\ Mississippi State University \\ Tess Astatkie \\ Dalhouse University
}

See next page for additional authors

Follow this and additional works at: https://digitalcommons.unl.edu/usdaarsfacpub

Zheljazkov, Valtcho D.; Vick, Brady A.; Baldwin, Brian S.; Buehring, Normie; Astatkie, Tess; and Johnson, Billy, "EFFECT OF PLANTING DATE, NITROGEN RATE, AND HYBRID ON SUNFLOWER" (2012). Publications from USDA-ARS / UNL Faculty. 1546.

https://digitalcommons.unl.edu/usdaarsfacpub/1546

This Article is brought to you for free and open access by the U.S. Department of Agriculture: Agricultural Research Service, Lincoln, Nebraska at DigitalCommons@University of Nebraska - Lincoln. It has been accepted for inclusion in Publications from USDA-ARS / UNL Faculty by an authorized administrator of DigitalCommons@University of Nebraska - Lincoln. 


\section{Authors}

Valtcho D. Zheljazkov, Brady A. Vick, Brian S. Baldwin, Normie Buehring, Tess Astatkie, and Billy Johnson 


\title{
EFFECT OF PLANTING DATE, NITROGEN RATE, AND HYBRID ON SUNFLOWER
}

\author{
Valtcho D. Zheljazkov, ${ }^{1}$ Brady A. Vick, ${ }^{2}$ Brian S. Baldwin, ${ }^{3}$ Normie Buehring, ${ }^{1}$ \\ Tess Astatkie, ${ }^{4}$ and Billy Johnson ${ }^{\mathbf{5}}$ \\ ${ }^{1}$ Mississippi State University, North Mississippi Research and Extension Center, Verona, \\ Mississippi, USA \\ ${ }^{2}$ Sunflower Research Unit, USDA-ARS, Northern Crop Science Laboratory, Fargo, North \\ Dakota, USA \\ ${ }^{3}$ Department of Plant and Soil Sciences, Mississippi State University, Mississippi State \\ University, Mississippi, USA \\ ${ }^{4}$ Faculty of Agriculture, Dalhouse University, Truro, Nova Scotia, Canada \\ ${ }^{5}$ Coastal Plain Experiment Station, Newton, Mississippi, USA
}

\begin{abstract}
$\square \quad$ Sunflower is a potential crop for the southeastern United States for production of cooking oil or biodiesel. In 2007, we evaluated the effect of planting date (PD, 20 April, 20 May, and 20 June), nitrogen ( $N$ ) application rate (0, 67, 134, and $202 \mathrm{~kg} \mathrm{ha}^{-1}$ ), and hybrid ('DKF3875', 'DKF2990', 'DKF3510', and 'DKF3901') on sunflower productivity and oil profile in four Mississippi locations, Newton, Starkville, and two sites in Verona. There was a trend of increased oleic acid concentration with earlier planting dates, especially in hybrids with lower oleic acid concentration. Earlier planting dates of 'DKF3901' and 'DKF2990' (the hybrid with the lowest oleic acid) actually had 200 to $300 \mathrm{~g}$ $\mathrm{kg}^{-1}$ higher concentration of oleic acid when grown in Mississippi vs. the original seed of the same hybrids used for planting and produced at a more northern latitude. This and a recent study in Mississippi suggest that modern hybrids could provide ample yields even when the $N$ fertilization is relatively low.
\end{abstract}

Keywords: fatty acid composition, oil content, oil yield, biodiesel

\section{INTRODUCTION}

The major sunflower (Helianthus annuus L.) production areas in North America include North Dakota, South Dakota, Colorado, Kansas, Minnesota, Nebraska, and Texas (Johnston et al., 2002; National Agricultural Statistics

Received 15 June 2010; accepted 31 August 2010.

Address correspondence to Valtcho D. Zheljazkov, University of Wyoming, Sheridan Research and Extension Center, 663 Wyarno Road, Sheridan, WY, 82801, USA. E-mail: vjeliazk@uwyo.edu 
Service, 2006) in the United States, and Manitoba and Saskatchewan in Canada (Angadi and Entz, 2002; Johnston et al., 2002). The fatty acid composition of sunflower oil is genotype dependent (Miller and Vick, 1999; Burton et al., 2004; Izquierdo and Aguirrezábal, 2008); however, it can also be significantly altered by the environment (Robertson et al., 1978; Lajara et al., 1990; Sobrino et al., 2003; Izquierdo and Aguirrezábal, 2008; Zheljazkov et al., 2008). As with other vegetable oils, the fatty acid profile of sunflower oil determines its nutritional properties and specific uses (Warner et al., 2003; Burton et al., 2004). Consumers prefer sunflower hybrids with mid-oleic or high-oleic acid content because of the health benefits associated with oleic acid (Jing et al., 1997; Krajcovicova-Kudlackova et al., 1997; $\mathrm{Hu}$ et al., 2001). There is limited amount of information on sunflower as a potential crop for the southeastern United States. The objective of this study was to evaluate the effects of hybrid, planting date, and nitrogen $(\mathrm{N})$ rate and the interactions of these factors on sunflower yield and seed oil oleic acid concentration under the hot humid environment of the southeastern United States. This work extends previous research on the effect of hybrid and $\mathrm{N}$ rate on sunflower yields, oil content, and fatty acid profile (Zheljazkov et al., 2008).

\section{MATERIALS AND METHODS}

\section{Field Experiments}

A field experiment was conducted during the 2007 cropping season at four locations in Mississippi: Newton (33.43 $\mathrm{N}$ lat), Starkville (33.47 $\mathrm{N}$ lat), and two sites in Verona $\left(34.16^{\circ} \mathrm{N}\right.$ lat). Treatments included planting date (20 April, 20 May, and 20 June), hybrid ('DKF3875', 'DKF2990', 'DKF3510', and 'DKF3901'), and $\mathrm{N}$ rate $\left(0,67,134\right.$, and $\left.202 \mathrm{~kg} \mathrm{ha}^{-1}\right)$. The certified sunflower seed of the four hybrids were obtained from Monsanto Co. (St. Louis, MO, USA) and produced in Woodland, CA (38.41 ${ }^{\circ} \mathrm{N}$ lat.). 'DKF3875' is a traditional type; 'DKF2990' is a traditional type and downy mildew resistant; 'DKF3510' is a mid-oleic acid type (NuSun) and downy mildew resistant; and 'DKF3901' is a traditional type and downy mildew resistant. The seed of the original four hybrids (used for planting) had different fatty acid concentrations (Table 1). Based on oleic acid concentration, 'DKF3510' is a mid-oleic sunflower, 'DKF3875' and 'DKF2990' are the traditional class of sunflower with high polyunsaturated fatty acid (linoleic), whereas 'DKF3901' is a traditional acid sunflower, intermediate in both oleic and linoleic acid compared to the high and low values of other hybrids (Canadian Food Inspection Agency, 2007; Codex Alimentarius Committee, 2005).

The four locations for the experiment were chosen to represent growing areas from south to north Mississippi and different soil types. The soil at Newton was a Prentiss fine sandy loam (coarse-loamy, siliceous, 
TABLE 1 Mean fatty acid concentrations of the original certified seed of the four sunflower cultivars. The analysis of variance and subsequent results in the following tables are based on the response measurements minus these values to correct for the differences among the cultivars

\begin{tabular}{|c|c|c|c|c|c|c|c|c|}
\hline Hybrid & Palmitic & Stearic & Oleic & Linoleic & Arachidic & Gondoic & Behenic & Lignoceric \\
\hline & & & & & $-\mathrm{g} \mathrm{kg}^{-1}$ & & & \\
\hline 'DKF2990' & 67.8 & 53.9 & 262.0 & 561.0 & 3.1 & 1.7 & 7.0 & 1.8 \\
\hline 'DKF3510' & 41.4 & 43.1 & 862.0 & 31.0 & 4.0 & 2.4 & 10.5 & 3.6 \\
\hline 'DKF3875' & 65.3 & 40.3 & 402.0 & 459.0 & 3.3 & 1.4 & 8.3 & 2.6 \\
\hline 'DKF3901' & 62.0 & 64.6 & 328.0 & 509.0 & 4.7 & 1.3 & 10.3 & 2.5 \\
\hline
\end{tabular}

semiactive, thermic, Glossic Fragiudult) with $\mathrm{pH}$ 6.9, the soil in Starkville was a Marietta fine sandy loam (find-loamy, siliceous, active, thermic Fluvaguentic Eutrudept) with $\mathrm{pH}$ 5.2, the soil at the Verona 1 location was a Catalpa silty loam (fine, montmorrillonitie, thermic, Fluvaguentic Halludoll) with $\mathrm{pH}$ 7.1, and the soil at Verona 2 location was a Quitman sandy loam (fine-loamy, siliceous, semiactive, thermic, Aquic Paleudult) with $\mathrm{pH}$ 5.9 .

\section{Soil Nutrient Analyses}

Prior to planting, representative soil samples were taken at the four experimental sites, air-dried, ground to pass through a 1-mm sieve, and extracted using the Lancaster soil test method (Cox, 2001). The concentration of phytoavailable nutrients was determined by an inductively coupled argon plasma spectrometer (Perkin Elmer, Norwalk, CT, USA). Following the soil analysis, phosphorus $(\mathrm{P})$ and potassium (K) fertilizers were broadcast and incorporated at each location. Nitrogen (as urea-ammonium nitrate solution $32 \% \mathrm{~N}$ ) was knifed in on either side of the row (20-25 cm from row centers) and applied in $67 \mathrm{~kg} \mathrm{ha}^{-1}$ increments: the first $67 \mathrm{~kg} \mathrm{ha}^{-1}$ increment was applied at planting, the side dressing was applied a month later at the V-4 growth stage, and the last one at V-6 (Schneiter and Miller, 1981).

\section{Plant Growth Conditions}

Land preparation at the four locations was conducted following the procedure for row crops soil preparation in the region: disking and formation of raised beds at 97 to $102 \mathrm{~cm}$ center to center at the beginning of April. The herbicide Treflan [trifluralin; 2,6-dinitro- $N, N$-dipropyl-4-(trifluoromethyl) benzenamine] at 4.5 to $5.6 \mathrm{~kg} \mathrm{ha}^{-1}$ (preplant incorporated, right after the formation of raised beds) was applied to improve weed control at the four locations. Individual experimental units (plots) were $6 \mathrm{~m}$ by $4 \mathrm{~m}$. Sunflower seed was planted at the four locations using a cone planter at 3.8-cm depth, at 97 - to $102-\mathrm{cm}$ interrow space, and a seeding rate of 6.4 seeds $\mathrm{m}^{-1}$ of linear row. Different seed sizes of the four hybrids (and different 1000-seed 
weight) resulted in different seeding rates (by weight) for the hybrids, but seeding rate was the same for a particular hybrid at every location. Seeding rates were $3.47,5.12,4.37$, and $4.13 \mathrm{~kg} \mathrm{ha}^{-1}$ for the hybrids 'DKF2990', 'DKF3510', 'DKF3875', and 'DKF3901', respectively.

When all plants in a given treatment reached maturity (after physiological stage R-9) (Schneiter and Miller, 1981), the two inner rows in each plot were harvested. Sunflower seed was threshed on a stationary thresher (Almaco, LPR-E, Nevada, IA, USA), and seed moisture was determined by a stationary electronic grain-moisture tester (Model GAC2000, Dickey-John, Auburn, IL, USA) in a 500-g sample from each plot. Sunflower seed subsamples (100 $\mathrm{g}$ from each plot) were further cleaned by hand to remove any broken seed or impurities, placed overnight in a freezer at $-20^{\circ} \mathrm{C}$ to prevent disease development and eliminate living insects, and then stored in a refrigerator at $4^{\circ} \mathrm{C}$ awaiting further analysis.

\section{Analysis of Sunflower Fatty Acid Composition and Seed Oil Content}

The sunflower subsamples from every plot in a location (cleaned as described above) were ground in a coffee grinder and sub-subsamples were extracted and analyzed on a Hewlett-Packard Model (Palo Alto, CA, USA) 5890 gas chromatograph (GC), fitted with a DB-23 capillary column (30 m by $0.25 \mathrm{~mm}$; J\&W Scientific, Folsom, CA, USA) as described previously (Zheljazkov et al., 2008). Seed oil content was estimated on a 40-mL sample from each plot of cleaned, weighed seed using a Maran Ultra Resonance nuclear magnetic resonance (NMR) instrument (Resonance Instruments Ltd., Witney, UK), following the American Oil Chemists Society Official Methods and Recommended Practices, AK4-95 (American Oil Chemists Society, 1994). At harvest, seeds from different treatments had various moisture contents. To make the results comparable, oil contents were adjusted to $100 \mathrm{~g}$ $\mathrm{kg}^{-1}$ moisture content.

\section{Statistical Methods}

Within each of the four locations (Newton, Starkville, Verona 1, and Verona 2), the experimental field had four blocks; each block was partitioned into three parts, which were randomly assigned to one of the three planting dates (1, 2, and 3). Within each planting date the 16 combinations of hybrid ('DKF2990', 'DKF3510', 'DKF3875', and 'DKF3901') and N rate $\left(0,67,134\right.$, and $\left.202 \mathrm{~kg} \mathrm{ha}^{-1}\right)$ were completely randomized. For each location, this layout made the design a split-plot factorial with planting dates (PDs) as the whole-plot treatments and the factorial of hybrid and $\mathrm{N}$ rate as the subplot treatments. The three factors of interest (PD, hybrid, and $\mathrm{N}$ rate) were considered as fixed, and block was considered as random. Seed 
yield response was collected from all four blocks, but oil yield and oleic acid concentration responses were measured from three blocks. Analysis of variance was completed for each location using the Mixed Procedure of SAS (SAS Institute, Cary, NC, USA), and further multiple means comparison was completed for significant $(P<0.05)$ and marginally significant $(P$ value between 0.05 and 0.1 ) by comparing the least squares means of the corresponding treatment combinations. Letter groupings were generated using a $1 \%$ level of significance for two- or three-factor interaction effects and using a $5 \%$ level of significance for main effects. For each response, the validity of model assumptions on the error terms was verified by examining the residuals as described in Montgomery (2005) and appropriate transformations were applied on responses that violated assumptions.

\section{RESULTS AND DISCUSSION}

\section{Seed Yields}

The ANOVA $P$ values of the main and interaction effects on seed yield (Table 2) indicated that there was a significant interaction effect of planting date and hybrid at the Newton and two Verona locations, whereas the main effect of $\mathrm{N}$ rate was significant only at the Verona 1 location. Also, there was a significant interaction effect of hybrid and $\mathrm{N}$ rate at the Verona 2 location, while the three-way interaction effect between planting date, hybrid, and $\mathrm{N}$ rate was significant at Starkville. At Verona 1, N rates at 67 and $202 \mathrm{~kg}$ $\mathrm{ha}^{-1}$ increased seed yields relative to the untreated control. Seed yields at Newton (the southernmost location) were higher in the first planting date, reduced in the second planting date, and lowest at the third planting date (Figure 1). The third planting date at Verona 1 resulted in lower seed yields from 'DKF3510' and 'DKF3875' relative to the first and second planting date (Figure 1). The second planting date for 'DKF2990' was higher than the first or the third. The second planting date for 'DKF3901' resulted in

TABLE 2 ANOVA $P$ values for the main and interaction effects of planting date (PD), hybrid, and N rate on seed yield $\left(\mathrm{kg} \mathrm{ha}^{-1}\right)$ at four locations in Mississippi

\begin{tabular}{lcccc}
\hline $\mathrm{SV}^{\dagger}$ & Newton & Starkville & Verona 1 & Verona 2 \\
\hline $\mathrm{PD}$ & 0.001 & 0.023 & 0.002 & 0.000 \\
Hybrid & 0.001 & 0.001 & 0.001 & 0.001 \\
$\mathrm{PD} \times$ hybrid & $\underline{0.001}^{\dagger \dagger}$ & 0.672 & $\underline{0.001}$ & $\underline{0.001}$ \\
$\mathrm{~N}$ rate & 0.311 & 0.021 & $\underline{0.413}$ & 0.594 \\
$\mathrm{PD} \times \mathrm{N}$ rate & 0.774 & 0.101 & 0.183 & $\underline{0.052}$ \\
$\mathrm{Hybrid} \times \mathrm{N}$ rate & 0.651 & 0.831 & 0.764 & 0.206 \\
$\mathrm{PD} \times$ hybrid $\times \mathrm{N}$ rate & 0.273 & $\underline{0.098}$ & & \\
\hline
\end{tabular}

${ }^{\dagger} \mathrm{SV}$ - Source of variation.

${ }^{\dagger}$ Significant effects that needed multiple means comparison are underlined. 


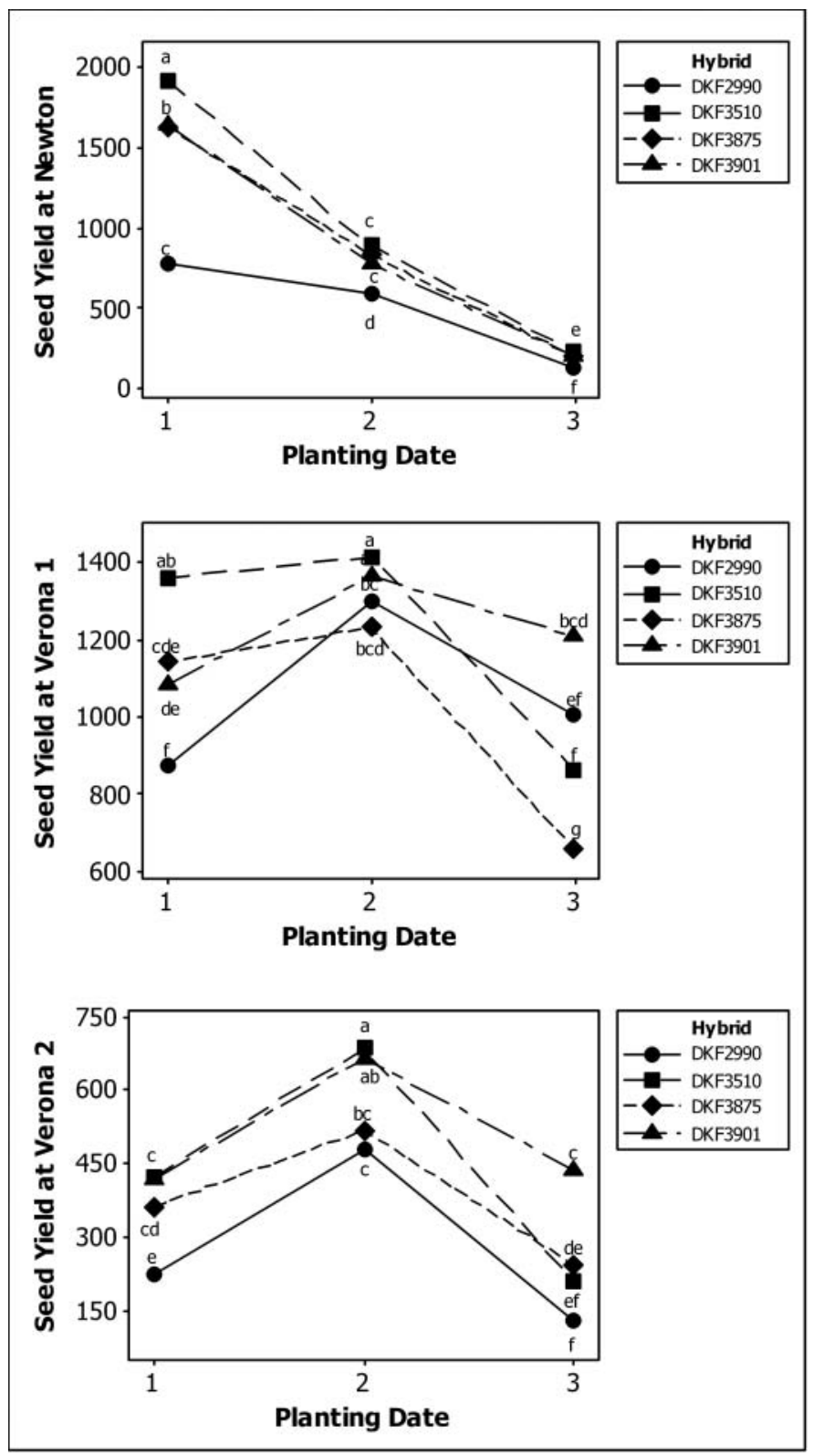

FIGURE 1 Interaction plot of seed yield $\left(\mathrm{kg} \mathrm{ha}^{-1}\right)$ versus planting date for the four hybrids at the Newton, Verona 1, and Verona 2 locations. Means sharing the same letter are not significantly different at the $1 \%$ level of significance.

higher seed yields than the first but was not different from the third planting date (Figure 1). Overall, in the first and the second planting date 'DKF3510' provided higher yields than 'DKF2990'. The third planting date resulted in lower seed yields at Verona 2 relative to the second planting (Figure 1). The 


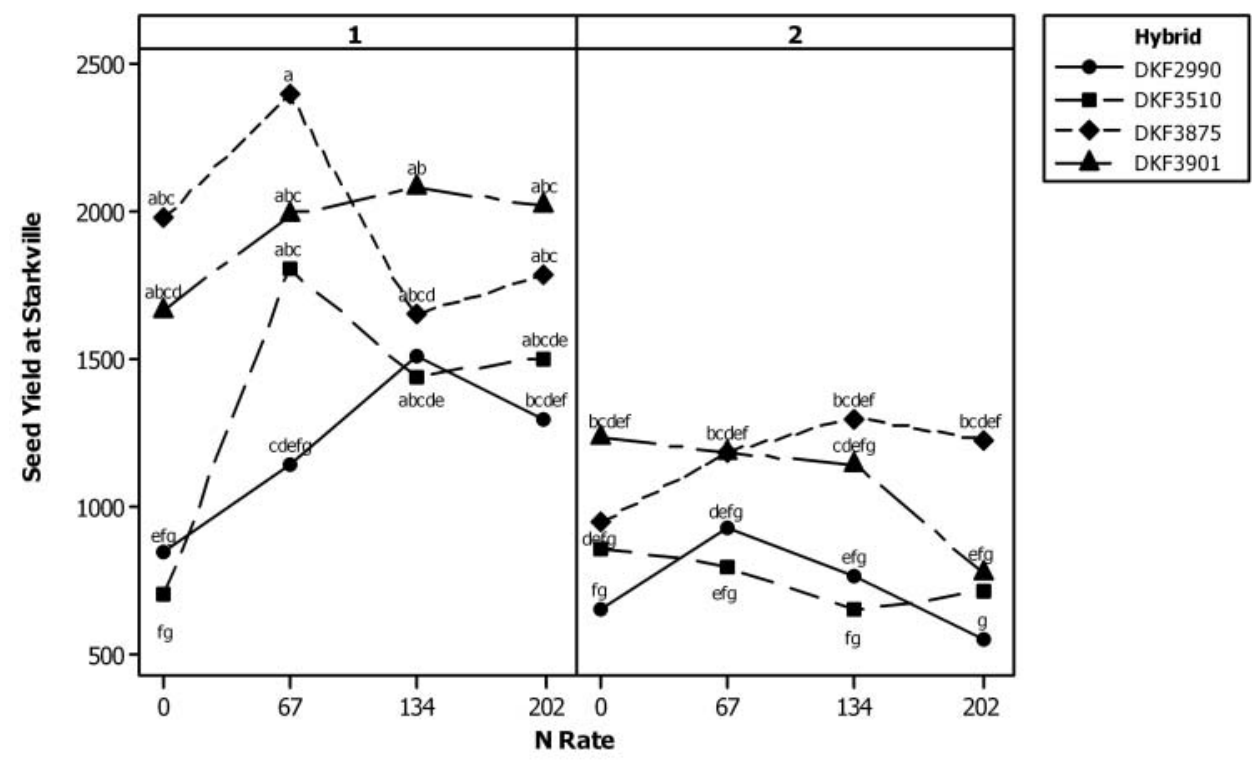

Panel variable: Planting Date

FIGURE 2 Interaction plot of seed yield $\left(\mathrm{kg} \mathrm{ha}^{-1}\right)$ versus $\mathrm{N}$ rate for the four hybrids and two planting dates at the Starkville location. Means sharing the same letter are not significantly different at the $1 \%$ level of significance.

second planting at Verona 2 had higher seed yields of 'DKF3510', 'DKF3901', and 'DKF2990' than either the first or the third planting, while seed yields of 'DKF3875' were higher from the second planting relative to the third, but not significantly different from the first planting. Generally, 'DKF3510' and 'DKF3901' at Verona 2 provided higher yields than 'DKF2990'. With the exception of 'DKF3510', seed yields in Starkville from the first planting date were not affected by $\mathrm{N}$ rate (Figure 2).

\section{Oil Yields}

There was a significant interaction effect of planting date and hybrid at the Newton and two Verona locations, planting date and $\mathrm{N}$ rate at the Starkville location, and hybrid and $\mathrm{N}$ rate at the Verona 1 location (Table 3). The main effect of hybrid was significant at Starkville, and N rate was significant at Newton. In general, oil yields at Newton (the most southern location) were higher from the first planting date, lower from the second planting, and lowest in the third planting date (Figure 3). However, at the Verona 2 location, oil yields were generally higher from the first and the second planting date and lower from the third planting (Figure 3).

At Starkville, the fertility applications increased oil yields relative to the untreated control from the first planting date (data not shown). However, the fertility treatments had no significant effect on oil yields from the second 
TABLE 3 ANOVA $P$ values for the main and interaction effects of planting date (PD), hybrid, and N rate on oil yield $\left(\mathrm{kg} \mathrm{ha}^{-1}\right)$ at four locations in Mississippi

\begin{tabular}{|c|c|c|c|c|}
\hline $\mathrm{SV}^{\dagger}$ & Newton & Starkville & Verona 1 & Verona 2 \\
\hline PD & 0.001 & 0.004 & 0.012 & 0.001 \\
\hline Hybrid & 0.001 & 0.001 & 0.001 & 0.001 \\
\hline $\mathrm{PD} \times$ hybrid & $\underline{0.001}^{\dagger \dagger}$ & $\overline{0.776}$ & $\underline{0.001}$ & $\underline{0.079}$ \\
\hline $\mathrm{N}$ rate & $\overline{0.008}$ & 0.107 & $\overline{0.001}$ & $\overline{0.201}$ \\
\hline $\mathrm{PD} \times \mathrm{N}$ rate & $\overline{0.317}$ & 0.023 & 0.514 & 0.273 \\
\hline Hybrid $\times \mathrm{N}$ rate & 0.307 & $\overline{0.944}$ & 0.024 & 0.120 \\
\hline $\mathrm{PD} \times$ hybrid $\times \mathrm{N}$ rate & 0.128 & 0.731 & $\overline{0.170}$ & 0.296 \\
\hline
\end{tabular}

${ }^{\dagger} \mathrm{SV}$ - Source of variation.

${ }^{\dagger \dagger}$ Significant effects that needed multiple means comparison are underlined.

planting date. Also, at the Verona 1 location, fertility treatments did not generally affect oil yields from the three planting dates. Oil yields from the first and especially from the second planting date at Verona 1 were greater than the oil yields from the third planting date.

\section{Oleic Acid Concentration}

There was a significant planting date $\times$ hybrid interaction at the Starkville and Verona 2 locations, and hybrid $\times \mathrm{N}$ rate interaction at the Starkville and

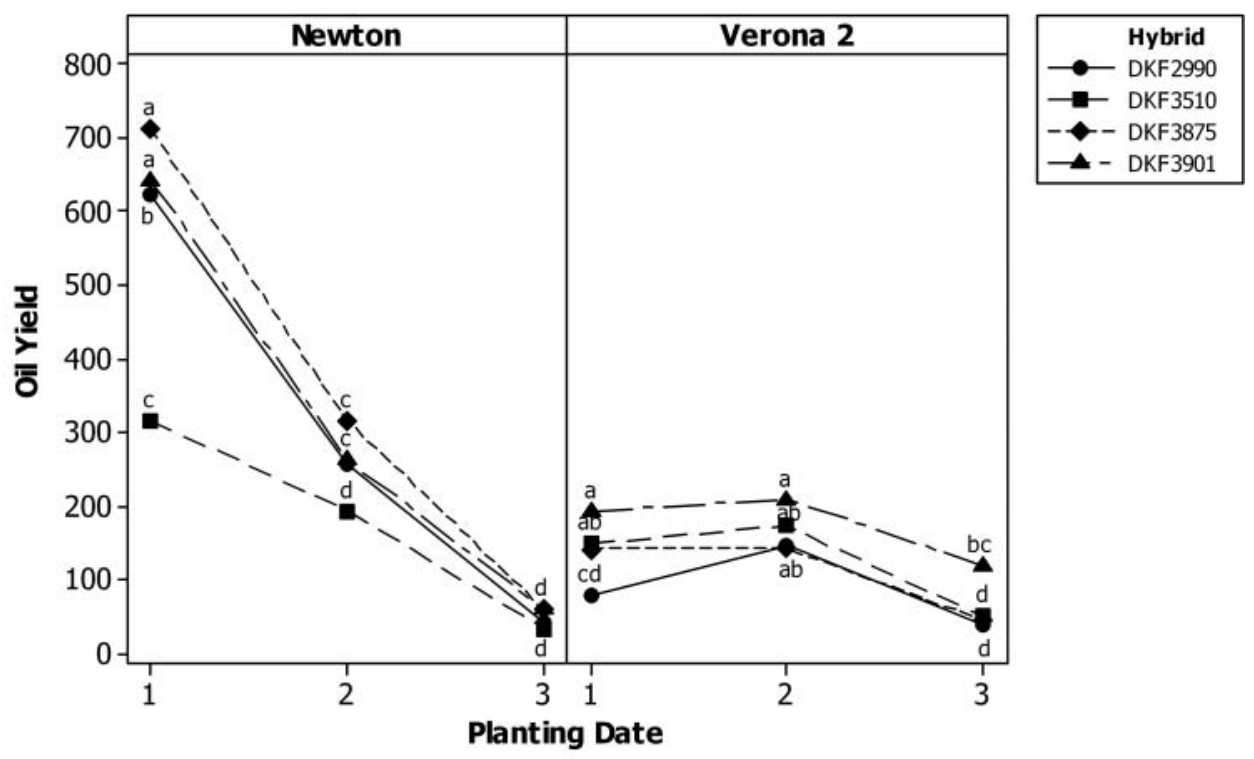

\section{Panel variable: Location}

FIGURE 3 Interaction plot of oil yield versus planting date for the four hybrids at the Newton and Verona 2 locations. Within each location, means sharing the same letter are not significantly different at the $1 \%$ level of significance. 
TABLE 4 ANOVA $P$ values for the main and interaction effects of planting date (PD), hybrid, and N rate on adjusted oleic FA at four locations in Mississippi

\begin{tabular}{lcccc}
\hline $\mathrm{SV}^{\dagger}$ & Newton & Starkville & Verona 1 & Verona 2 \\
\hline $\mathrm{PD}$ & 0.001 & 0.011 & 0.001 & 0.001 \\
Hybrid & 0.001 & 0.001 & 0.001 & 0.001 \\
$\mathrm{PD} \times$ hybrid & 0.001 & $\underline{0.049}$ & 0.001 & $\underline{0.001}$ \\
$\mathrm{~N}$ rate & 0.239 & 0.482 & 0.001 & 0.350 \\
$\mathrm{PD} \times \mathrm{N}$ rate & 0.906 & $\underline{0.068}$ & 0.118 & 0.940 \\
$\mathrm{Hybrid} \times \mathrm{N}$ rate & 0.097 & 0.209 & $\underline{0.045}$ & $\underline{0.015}$ \\
$\mathrm{PD} \times$ hybrid $\times \mathrm{N}$ rate & $\underline{0.043}$ & & & 0.953 \\
\hline
\end{tabular}

$\dagger$ SV - Source of variation.

${ }^{\dagger}$ Significant effects that needed multiple means comparison are underlined.

Verona 2 locations. The three-way interaction (planting date $x$ hybrid $\times$ $\mathrm{N}$ rate) was significant at the Newton and Verona 1 locations (Table 4). Generally, there was a trend for increased oleic acid concentration with earlier planting dates, the trend being more pronounced for hybrids with lower oleic acid concentration in the original seed (Figure 4). Another important observation is that earlier planting dates of 'DKF3901' and 'DKF2990' (the hybrid with the lowest oleic acid in original seed) actually had 200 to $300 \mathrm{~g} \mathrm{~kg}^{-1}$ higher concentration of oleic acid when grown in Mississippi compared to the original seed, produced in northern California.

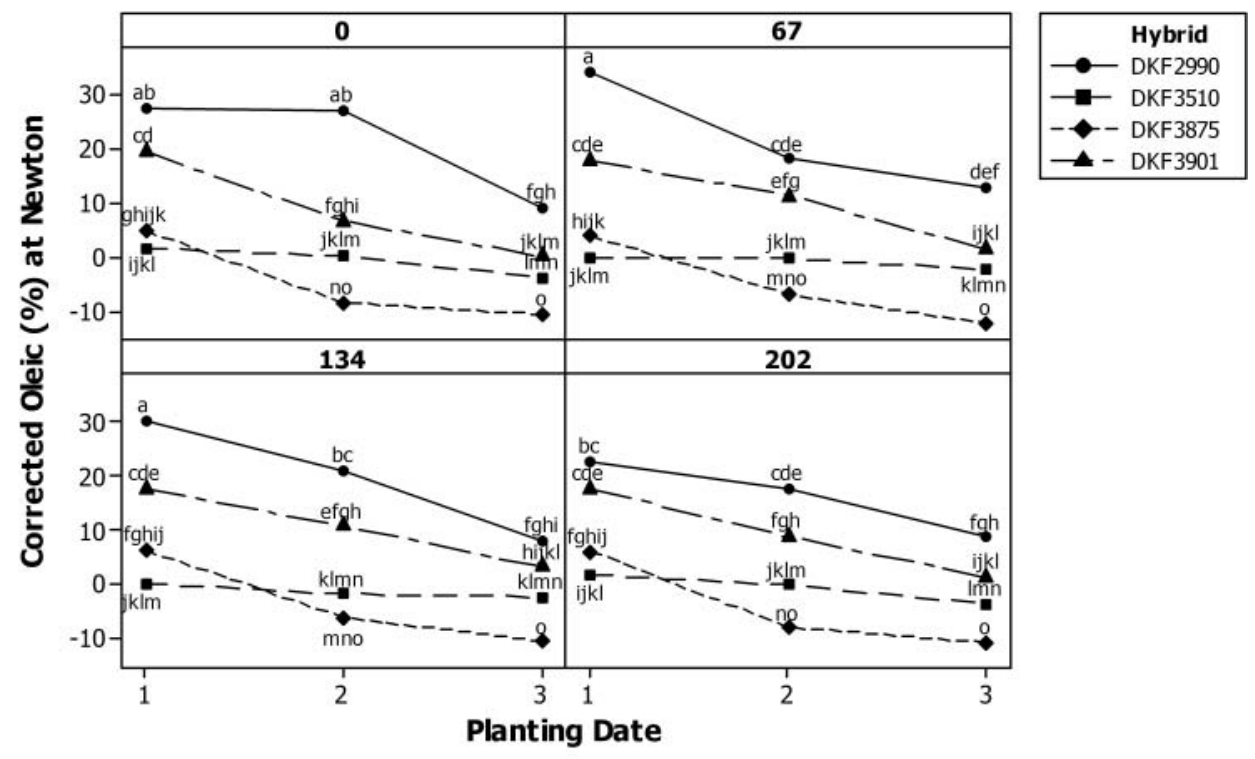

\section{Panel variable: N Rate}

FIGURE 4 Interaction plot of adjusted oleic $\left(\mathrm{g} \mathrm{kg}^{-1}\right)$ versus planting date for the four hybrids and the four $\mathrm{N}$ rates at the Newton location. Means sharing the same letter are not significantly different at the $1 \%$ level of significance. 
The oleic acid of 'DKF3875' in earlier planting dates tended to be up to $100 \mathrm{~g} \mathrm{~kg}^{-1}$ higher, whereas in later planting dates it was up to $100 \mathrm{~g} \mathrm{~kg}^{-1}$ lower than in the original seed (Figure 4). The oleic acid of 'DKF3510' (the hybrid with mid-oleic acid) tended to be similar to the original seed.

At Starkville, the oleic acid of 'DKF2990' and 'DKF3901' was 200 to $300 \mathrm{~g} \mathrm{~kg}^{-1}$ higher than their respective concentrations in the original seed (Figure 5). At the Verona 2 location, this effect was less pronounced and similar to the results in Newton, where the oleic acid concentration of 'DKF3510' (the highest oleic acid hybrid) did not fluctuate relative to the original seed (Figure 5). The oleic acid concentration of 'DKF3901' at earlier planting date at Starkville was higher than the later planting date (Figure 5). Nitrogen at $67 \mathrm{~kg} \mathrm{ha}^{-1}$ to 'DKF2990' at Starkville increased oleic acid concentration relative to the 0 or $134 \mathrm{~kg} \mathrm{ha}^{-1} \mathrm{~N}$ rates, but was not different from the $202 \mathrm{~kg}$ $\mathrm{ha}^{-1} \mathrm{~N}$ rate. Earlier planting of 'DKF2990', 'DKF3901', and 'DKF3875' in the Verona 2 location resulted in a higher concentration of oleic acid than the third planting date (Figure 5). The $134 \mathrm{~kg} \mathrm{ha}^{-1} \mathrm{~N}$ rate had higher oleic acid concentration in 'DKF2990' than the $67 \mathrm{~kg} \mathrm{ha}^{-1} \mathrm{~N}$ rate, but not different from the 0 or $202 \mathrm{~kg} \mathrm{ha}^{-1} \mathrm{~N}$ rates (Figure 5). Generally, in the Newton, Starkville, and Verona 2 locations, the lower oleic acid hybrids ('DKF2990', 'DKF3875', and 'DKF3901') had higher concentrations of oleic acid when grown in Mississippi relative to the respective original seed (Figures 4 and 5).
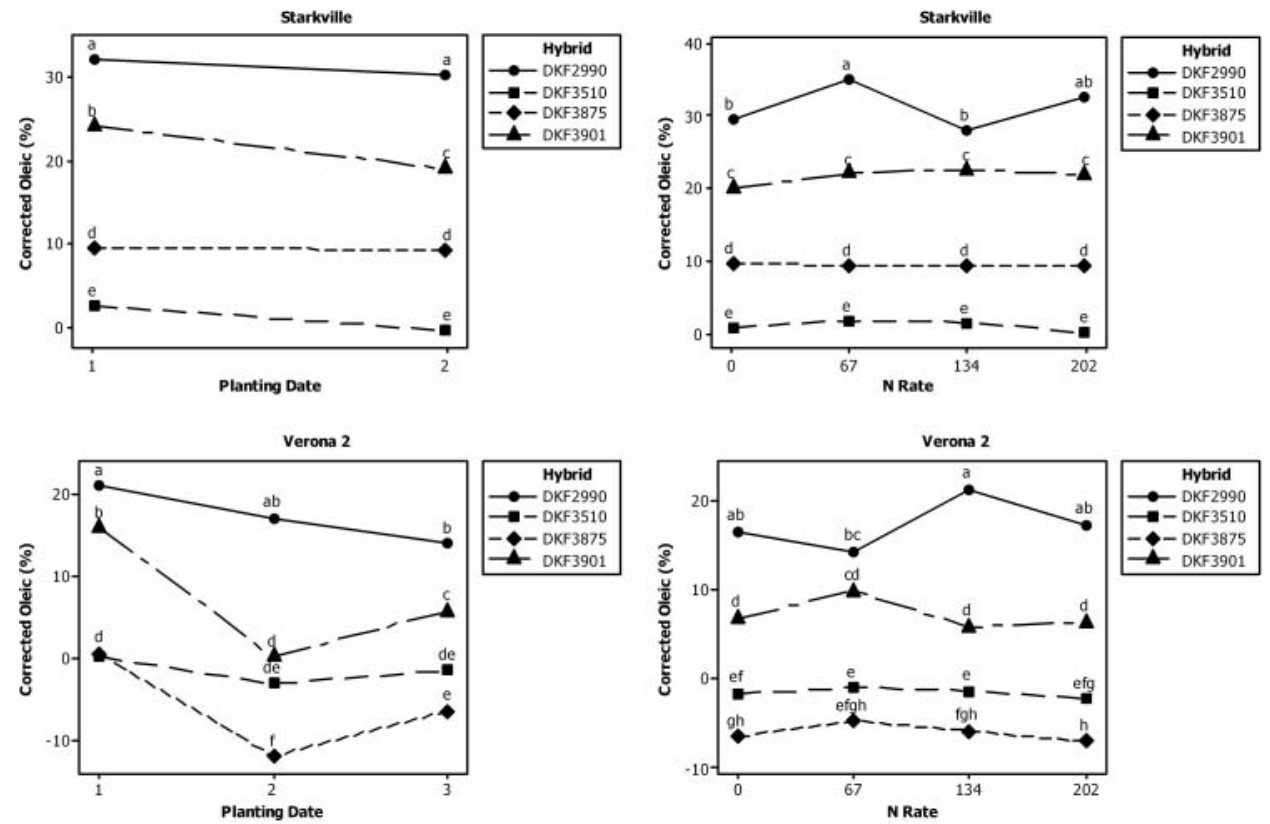

FIGURE 5 Interaction plot of adjusted oleic $\left(\mathrm{kg} \mathrm{ha}^{-1}\right)$ versus planting date and $\mathrm{N}$ rate for the four hybrids at the Starkville and Verona 2 locations. Within each location, means sharing the same letter are not significantly different at the $1 \%$ level of significance. 
An observation in this study and a previous report (Zheljazkov et al., 2008) was that low and mid-oleic acid sunflower hybrids grown in Mississippi will increase the concentration of oleic acid relative to their respective original seed (used for planting and produced in a more northern latitude, at $38^{\circ} 41^{\prime} \mathrm{N}$ lat). This increase in the accumulation of oleic acid of traditional sunflower transforms them into mid-oleic acid or NuSun hybrids (National Sunflower Association, 2009). The increase in oleic acid concentration could bring a higher price for producers and an increased marketability for producers and processors. An earlier report demonstrated the increase in oleic acid in sunflower from northern to southern locations (Robertson et al., 1978). Sobrino et al. (2003) found that an important factor for oleic acid accumulation was the temperature during development and maturation of sunflower achenes.

\section{CONCLUSIONS}

Overall, this and previous studies in Mississippi (Homenauth et al., 1986; Zheljazkov et al., 2008) demonstrated that sunflower could be a viable crop in the hot humid southeastern United States. However, with the exception of Zheljazkov et al. (2008), previous reports were on old sunflower varieties that are no longer available. Seed and oil yields in this study were similar to previous reports on the same hybrids (National Sunflower Association, 2009; Zheljazkov et al., 2008); however, in this study there was an additional factor, planting date. Seed yields in this study were generally comparable to sunflower seed yields in the northern United States, the traditional sunflower production area (National Sunflower Association, 2009).

Generally, our results suggest that sunflower hybrids in more southern locations should be planted earlier, in April, whereas sunflower hybrids in more northern locations would be better suited for a later planting date in May and would provide high yields. Further delay in planting dates in Mississippi may significantly reduce seed and oil yields. This finding is important with respect to fitting the sunflower in rotations with winter field crops such as winter canola (Brassica napus L.), which is harvested in the first half of May.

This study and the previous one in Mississippi (Zheljazkov et al., 2008) suggested that modern sunflower hybrids could provide ample yields even when the $\mathrm{N}$ fertilization is relatively low $\left(67 \mathrm{~kg} \mathrm{ha}^{-1}\right)$ or none. This finding would come as no surprise in some areas of the world (e.g., Argentina) where sunflower is grown without fertilizers (Mercau et al., 2001; Ruiz and Maddonni, 2006). Sunflower is known to have a well-developed and deeply penetrating root system (Jaafar et al., 1993; Nielsen, 1998; Angadi and Entz, 2002; Stone et al., 2002) with efficient nutrient utilization (Valchovski, 2002). Hence, if sunflower is grown after winter oilseed crops, it could utilize the available residual nutrients efficiently, a clear benefit for the environment 
and the producers. The nonlinear pattern observed in the response of seed or oil yields to the $\mathrm{N}$ rates suggest that there may be other factors in the environment that were not controlled but may need to be included in future experiments.

The observed increase in oleic acid concentration relative to the original seed is an important finding; oleic acid has apparent nutritional benefits with regard to reduction of coronary heart disease ( Jing et al., 1997; KrajcovicovaKudlackova et al., 1997; Hu et al., 2001). Further, sunflower oils high in oleic acid do not need to be hydrogenated (a process resulting in unhealthy trans fats) and hence, have health advantages over other vegetable oils (canola, soybean). This makes high-oleic acid sunflower oil produced in Mississippi (and presumably in other southern locations) preferable to other vegetable oils.

\section{ACKNOWLEDGEMENTS}

Authors acknowledge financial support by the US Department of Energy for the Fedstock for Sustainable Energy Systems in Mississippi. We thank Thomas Horgan, Scott Horton, Robert Dobbs, Davis Clark, and Mark Harrison for their help in the field and laboratory. Contribution of the Mississippi Agricultural and Foresty Experiment Station Journal article no. J-11521.

\section{REFERENCES}

American Oil Chemists' Society. 1994. Official Methods and Recommended Practices of American Oil Chemists' Society. Champaign, IL: American Oil Chemists' Society Press.

Angadi, S. V., and M. H. Entz. 2002. Root system and water use patterns of different height sunflower cultivars. Agronomy Journal 94: 136-145.

Burton, J. W., J. F. Miller, B. A. Vick, R. Scarth, and C. C. Holbrook. 2004. Altering fatty acid composition in oil seed crops. Advances in Agronomy 84: 273-306.

Canadian Food Inspection Agency. 2007. Decisions: Fats, Oils and Fatty Acids. Available at: http://www.inspection.gc.ca/english/fssa/labeti/decisions/fatgrae.shtml (accessed 21 September 2012).

Codex Alimentarius Committee. 2005. Codex Standard for Named Vegetable Oils. Available at www.codex alimentarius.net/download/standards/336/CXS_210e.pdf.

Cox, M. S. 2001. The Lancaster soil test method as an alternative to the Mehlich 3 soil test method. Soil Science 166: 484-489.

Homenauth, O. P., J. E. Harison, J. O. Sanford, and P. K. McConnaughey. 1986. Efficiency and response of sunflower to rate and timing of banded nitrogen. Agronomy Journal 17: 921-935.

Hu, F. B, J. E. Manson, and W. C. Willett. 2001. Types of dietary fat and risk of coronary heart disease: A critical review. Journal of the American College of Nutrition 20: 5-19.

Izquierdo, N. G., and L. A. N. Aguirrezábal. 2008. Genetic variability in the response of fatty acid composition to minimum temperature during grain filling in sunflower. Field Crops Research 106: 116-125.

Jaafar, M. N., L. R. Stone, and D. E. Cordrum. 1993. Rooting depth and dry matter development of sunflower. Agronomy Journal 85: 281-286.

Jing, M., A. R. Folsom, L. Lewis, J. H. Eckfeldt, and J. Ma. 1997. Relation of plasma phospholipid and cholesterol ester fatty acid composition of carotid artery intima-media thickness: The artherosclerosis risk in communities (ARIC) study. American Journal of Clinical Nutrition 65: 551-559. 
Johnston, A. M., D. L. Tanaka, P. R. Miller, S. A. Brandt, D. C. Nielsen, G. P. Lanfond, and N. R. Riveland. 2002. Oilseed crops for semiarid cropping systems in the northern Great Plains. Agronomy Journal 94: 231-240.

Krajcovicova-Kudlackova, M., R. Simoncic, A. Bederova, and J. Klvanova. 1997. Plasma fatty acid profile and alternative nutrition. Annals of Nutrition and Metabolism 41: 365-370.

Lajara, J., U. Diaz, and R. D. Quidiello. 1990. Definite influence of location and climatic conditions on the fatty acid composition of sunflower oil. Journal of the American Oil Chemists Society 67: 618-623.

Mercau, J. L., V. O. Sadras, E. H. Satorre, C. Messina, C. Balbi, M. Uribelarrea, and A. J. Hall. 2001. On-farm assessment of regional and seasonal variation in sunflower yield in Argentina. Agricultural Systems 67: 83-103.

Miller, J. F., and B. A. Vick. 1999. Inheritance of reduced stearic and palmitic acid content in sunflower seed oil. Crop Science 39: 364-367.

Montgomery, D. C. 2005. Design and Analysis of Experiments. New York: Wiley.

National Agricultural Statistics Service (NASS). 2006. Acreage. Agricultural Statistics Board, U.S. Department of Agriculture, June 30, 2007. Available at usda.mannlib.cornell.edu/usda/nass/Acre/ 2000s/2006/Acre-06-30-2006.pdf (accessed June 2008).

National Sunflower Association (NSA). 2009. www.sunflowernsa.org (accessed January 2009).

Nielsen, D. C. 1998. Comparison of three alternative oilseed crops for the central Great Plains. Journal of Production Agriculture 11: 336-341.

Robertson, J. A., J. R. Chapman, and J. R. Wilson. 1978. Relation of days after flowering to chemical composition and physiological maturity. Journal of the American Oil Chemists Society 55: 266-269.

Ruiz, R. A., and G. A. Maddonni. 2006. Sunflower seed weight and oil concentration under different post-flowering source-sink ratios. Crop Science 46: 671-680.

Schneiter, A. A., and J. F. Miller. 1981. Description of sunflower growth stages. Crop Science 21: 901-903.

Sobrino, E., A. M. Tarquis, and M. C. Diaz. 2003. Modeling the oleic acid content in sunflower oil. Agronomy Journal 95: 329-334.

Stone, L. R., D. E. Goodrum, A. J. Schlegel, M. N. Jaafar, and A. H. Khan. 2002. Water depletion depth of grain sorghum and sunflower in the central high plains. Agronomy Journal 94: 936-943.

Valchovski, I. 2002. Influence of heavy rate of nitrogen fertilizer on oil content and fatty acid composition of different varieties and hybrids. Rasteniev'dni Nauki 39: 338-341.

Warner, K., B. A. Vick, L. Kleingartner, I. Isaac, and K. Doroff. 2003. Composition of sunflower Nusun, (mid-oleic sunflower) and high-oleic sunflower oils. Proceedings of the Sunflower Research Workshop, Fargo, ND, January 16-17. Available at: http://www.sunflowernsa.com/research/researchworkshop/documents/107.PDF (accessed 21 September 2012)

Zheljazkov, V. D., B. A. Vick, M. W. Ebelhar, N. Buehring, B. Baldwin, T. Astatkie, and J. F. Miller. 2008. Yield, oil content, and composition of sunflower (Helianthus annuus L.) grown at multiple locations in Mississippi. Agronomy Journal 100: 635-642. 